Jurnal Indonesia Sosial Teknologi: p-ISSN: 2723 - 6609

e-ISSN : 2745-5254

Vol. 2, No. 6 Juni 2021

\title{
PENGARUH SEKTOR TRANSPORTASI DAN PERGUDANGAN TERHADAP PDRB DI KOTA PADANG PERIODE 2018 - 2020
}

\author{
Agika Wasinta Br Sembiring, Silvya Rehgina Gumolung, Rahel Nur Hamidah, \\ Widiana Yeny, Michael Owen \\ Universitas Internasional Batam \\ Email: 1941127.agika@uib.edu, 1941123.silvya@uib.edu,191129.rahel@uib.edu, \\ 1941062.widiana@uib.edu,1941259.michael@uib.edu
}

\begin{abstract}
This research is an analysis of the influence of the transportation and warehousing sector on GDRP in Padang city for 3 years (2018-2020). This study aims to analyze and find out how the influence of transportation and warehousing sector on GDRP in the city of Padang period 2018 -2020 and the causative factors. The results of this study show that the influence of transportation and warehousing sector has a good influence and increased in 2018 and 2019 due to one of the reasons is the increasing demand for transportation. However, in 2020 it decreased due to one of the reasons for the covid-19 pandemic.
\end{abstract}

Keyword: transportation; warehousing; PDRB; Padang City

\begin{abstract}
Abstrak
Penelitian ini merupakan analisis pengaruh sektor pengangkutan dan pergudangan terhadap PDRB di Kota Padang selama 3 tahun (2018-2020). Penelitian ini bertujuan untuk menganalisis dan mengetahui bagaimana pengaruh sektor pengangkutan dan pergudangan terhadap PDRB di Kota Padang periode 2018 2020 dan faktor-faktor penyebabnya. Hasil penelitian ini menunjukkan bahwa pengaruh sektor pengangkutan dan pergudangan memiliki pengaruh yang baik dan meningkat pada tahun 2018 dan 2019 karena salah satu penyebabnya adalah meningkatnya permintaan akan transportasi. Namun, pada tahun 2020 berdampak kurang baik, dikarenakan menurunnya permintaan akibat salah satu penyebab pandemi Covid-19.
\end{abstract}

Kata kunci: transportasi; pergudangan; PDRB; Kota Padang

\section{Pendahuluan}

Untuk mengukur maju atau tidaknya suatu perekonomian daerah sebagai hasil dari program pembangunan daerah tersebut diperlukan alat pengukur yang tepat, salah satu nya Produk Domestik Regional Bruto (PDRB). Untuk menyusun PDRB dapat menggunakan dua pendekatan, yakni produksi dan penggunaan. Kedua pendekatan tersebut menyajikan komposisi data nilai tambah yang dirinci menurut sumber kegiatan ekonomi (lapangan usaha) dan menurut komponen penggunaannya. PDRB maupun agregat turunannya terbagi dalam dua versi penilaian, yaitu atas dasar "harga berlaku" 
Agika Wasinta Br Sembiring, Silvya Rehgina Gumolung, Rahel Nur Hamidah, Widiana Yeny, Michael Owen

serta atas dasar "harga konstan". Dalam sumber kegiatan lapangan usaha, terdapat beberapa faktor sektor yang mempengaruhi pertumbuhan PDRB, contohnya seperti transportasi dan pergudangan (Maharani, 2017).

Transportasi dan pergudangan merupakan suatu fungsi dari proses untuk menawarkan kesempatan yang baik dan mengurangi pemborosan secara keseluruhan sistem logistik. Transportasi bisa menjadi faktor yang mempengaruhi pertumbuhan PDRB dikarenakan setiap daerah tentu nya memiliki transportasi. Sudah cukup banyak ditemukan perusahaan-perusahaan transportasi yang berdiri beroperasi di berbagai daerah atau lazim melihat transportasi banyak dipakai oleh masyarakat, baik itu transportasi umum maupun pribadi. Hal ini dapat mempengaruhi dan bahkan mungkin bisa membantu pertumbuhan ekonomi di suatu daerah tersebut. Selain transportasi, pergudangan juga merupakan salah satu faktor sektor yang mempengaruhi pertumbuhan PDRB. Pergudangan merupakan suatu tempat yang bisa digunakan untuk menyimpan keperluan. Pergudangan semakin banyak ditemukan di beberapa daerah karena semakin banyak perusahaan yang membutuhkan suatu tempat untuk menyimpan barangbarangnya secara baik dan aman tanpa mengganggu kegiatan perusahaan (Abushaikha et al., 2018).

Salah satu daerah yang transportasi dan pergudangan nya mempengaruhi PDRB daerahnya adalah Kota Padang. Kota Padang adalah kota terbesar di pantai barat pulau Sumatra dan menjadi ibu kota provinsi Sumatera Barat. Kota Padang menjadi salah satu bagian dari wilayah Republik Indonesia yang telah berusaha untuk meningkatkan taraf hidup masyarakatnya melalui pembangunan di berbagai bidang. Kota Padang, cukup banyak ditemukan transportasi dan pergudangan. Salah satu alasan banyaknya ditemukan transportasi di Kota Padang adalah karena terdapat banyak tempat wisata. Sedangkan pergudangan cukup banyak ditemukan di Kota Padang, salah satu alasannya adalah karena masih banyak perusahaan-perusahaan di sana yang membutuhkan gudang untuk keperluan bisnis (Mulia \& Saputra, 2020).

Adapun alasan penulis perlu melakukan penelitian ini adalah untuk memenuhi tugas ujian tengah semester pada mata kuliah teori ekonomi makro dan untuk menambah pengetahuan tentang PDRB di Kota Padang. Paper ini difokuskan pada analisis PDRB Kota Padang selama 3 tahun, yaitu tahun 2018 - 2020. Dan untuk tujuan, penulis melakukan penelitian ini adalah untuk menganalisa dan mengetahui bagaimana pengaruh sektor transportasi dan pergudangan terhadap PDRB di Kota Padang periode 2018-2020 beserta faktor penyebabnya. Tujuan tersebut merupakan novelty dari penulis.

Menurut (Sinaga \& Hidayat, 2020), Transportasi merupakan suatu parameter untuk mengukur lajunya pertumbuhan ekonomi, transportasi juga bisa mempermudah mobilitas penduduk dari suatu daerah ke daerah lainnya. Perkembangan transportasi pada saat ini semakin kompleks, dengan berbagai macam jenis transportasi yang ditawarkan kepada masyarakat kereta api masih menjadi salah satu pilihan bagi masyarakat Indonesia. 
Sedangkan menurut Sukarto pengertian transportasi adalah perpindahan dari suatu tempat ke tempat lainnya dengan memakai alat pengangkutan, baik yang digerakkan oleh tenaga manusia, hewan (kuda, sapi, kerbau) ataupun mesin. Konsep transportasi didasarkan pada adanya suatu perjalanan (trip) antara asal (origin) dan tujuan (destination) (Manueke et al., 2018).

Menurut (Mahroof, 2019), Pergudangan merupakan inti dari sistem logistik dengan banyak teknologi yang digunakan dalam sebuah pengaturan untuk memastikan produk diidentifikasi, ditelusuri, dan dilacak di seluruh gudang.

Kegiatan pergudangan harus memiliki sistem penyimpanan yang baik agar bisa menunjang kelancaran dalam proses produksi ataupun aktivitas-aktivitas pergudangan. Namun, suatu gudang bisa dikatakan efektif dan efisien dapat dilihat dalam berbagai aspek, contoh nya penyimpanan material maupun produk. Gudang dan pergudangan penting bagi suatu perusahaan karena bisa mempengaruhi pendapatan perusahaan. Sistem pergudangan yang kurang baik dapat menyebabkan terjadinya barang kadaluarsa, kehilangan barang dan lain sebagainya yang pada akhirnya bisa mengurangi pendapatan perusahaan (Pitoy et al., 2020).

Menurut (Bintang \& Woyanti, 2018), Produk Domestik Regional Bruto (PDRB) adalah salah satu indikator yang digunakan untuk mengukur suatu kinerja perekonomian pada daerah dalam suatu periode. PDRB merupakan jumlah nilai tambah yang dihasilkan dari seluruh unit usaha pada suatu daerah tertentu bisa juga dikatakan sebagai jumlah dari nilai barang dan jasa akhir yang dihasilkan oleh seluruh unit ekonomi.

GDRP adalah jumlah dari semua unit bisnis yang dibentuk dari barang dan jasa bernilai tambah yang dihasilkan oleh semua kegiatan ekonomi suatu wilayah dalam jangka waktu tertentu. Selain pertumbuhan ekonomi, terdapat beberapa indikator yang dihasilkan seperti indeks implisit, tingkat implisit, dan beberapa lainnya ( 2020).

Ada banyak faktor yang mempengaruhi pertumbuhan PDRB, beberapa faktor diantaranya adalah tingkat pendidikan, dimana pertumbuhan PDRB erat hubungannya dengan sumber daya manusia. Faktor lainnya yang juga mempengaruhi yaitu pengeluaran pemerintah, peningkatan pengeluaran pemerintah dapat menyebabkan semakin bertambahnya pendapatan daerah, karena peningkatan agregat demand akan mendorong kenaikan investasi dan pada akhirnya menyebabkan kenaikan produksi (Fahlewi et al., 2020).

\section{Metode Penelitian}

Menurut (Sugiyono, 2016) metode penelitian pada dasarnya adalah cara ilmiah untuk mendapatkan data dengan tujuan dan kegunaan tertentu (Apriyani \& Pulungan, 2020). Berikut ini, penulis akan menyajikan berupa metode analisis, teknik pengumpulan data, serta populasi dan sampel penelitian.

Penelitian ini menggunakan metode analisis data kuantitatif. Analisis data kuantitatif merupakan proses menyajikan dan menginterpretasikan data dalam bentuk 
Agika Wasinta Br Sembiring, Silvya Rehgina Gumolung, Rahel Nur Hamidah, Widiana Yeny, Michael Owen

angka dengan menggunakan teknik statistik yang bertujuan untuk mendeskripsikan serta menjelaskan fenomena yang diteliti. Dalam menggunakan metode analisis kuantitatif, penulis menggunakan analisis deskriptif. Penulis akan melampirkan data dalam bentuk angka dan akan menjelaskan atau mendeskripsikan data tersebut.

Untuk sumber data, penulis memperoleh data dengan data sekunder. Data sekunder merupakan data yang didapat dengan tidak secara langsung dari pihak yang bersangkutan ataupun bisa dikatakan dengan cara melalui perantara. Data sekunder dapat diperoleh dengan cara menggunakan jurnal, buku, website, dan lain sebagainya. Tujuan penulis menggunakan data sekunder adalah dikarenakan lebih mudah diperoleh dan tidak membutuhkan waktu serta biaya yang banyak. Adapun sumber data yang diperoleh dari BPS Kota Padang dan artikel atau jurnal.

Mengumpulkan data, penulis menggunakan teknik data dokumentasi. Teknik pengumpulan dokumentasi adalah mengumpulkan beberapa data yang berhubungan dengan variabel penelitian. Adapun cara penulis mengumpulkan data melalui teknik dokumentasi yaitu dengan memperoleh data melalui Badan Pusat Statistik Kota Padang yang dikeluarkan oleh BPS Kota Padang periode 2018-2020 dan di perbaharui pada tanggal 02 maret 2021. Selain melalui BPS Kota Padang, penulis juga memperoleh data dari beberapa jurnal atau artikel.

Menurut (Sugiyono, 2017) populasi adalah generalisasi yang terdiri dari objekobjek maupun subjek yang mempunyai berbagai karakteristik tertentu dan ditetapkan oleh peneliti sebelumnya untuk bisa dipahami dan kemudian dapat ditarik kesimpulan oleh peneliti (Yulia \& Ningsih, 2020).

Populasi pada penelitian ini adalah 2 sektor yang termasuk di dalam PDRB atas dasar harga konstan 2010 menurut lapangan usaha pada periode 2018 - 2020. Adapun 2 sektor tersebut adalah sektor transportasi dan pergudangan. Pemilihan sampel penelitian yaitu berdasarkan dengan metode purposive sampling, yakni memilih sampel berdasarkan dari berbagai pertimbangan tertentu (Hanif \& Bustamam, 2017).

\section{Hasil dan Pembahasan}

Berdasarkan data yang didapatkan dari BPS Kota Padang untuk PDRB atas dasar harga konstan pada tahun 2010 menurut lapangan usaha, berikut terlampir tabel pengaruh sektor transportasi dan pergudangan terhadap PDRB Kota Padang. 


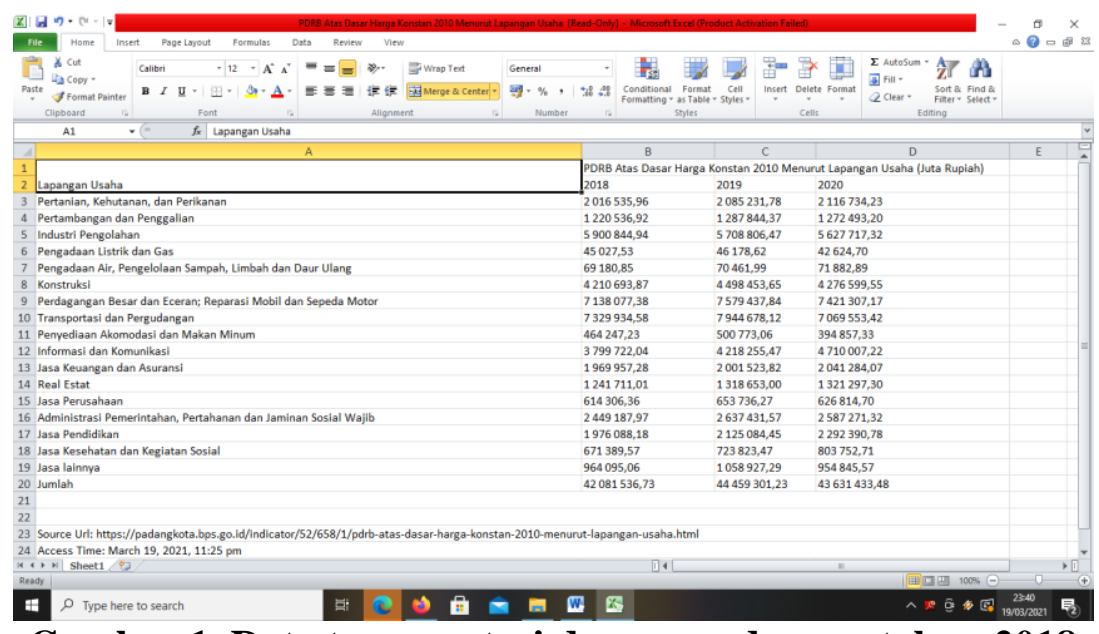

Gambar 1. Data transportasi dan pergudangan tahun 2018

Untuk sektor transportasi dan pergudangan, dapat dilihat jika pada tahun 2018 tertera 7.329.934,58 (dalam juta rupiah), dan untuk tahun 2019 meningkat dengan harga 7.944.678,12 (dalam juta rupiah), sedangkan untuk tahun 2020 menurun dengan harga 7.069.553,42 (dalam juta rupiah). Meskipun beberapa sektor juga menurun pada tahun 2020, namun sektor transportasi dan pergudangan yang menurun paling banyak diantara sektor lainnya yaitu menurun 875.124,7.

Meskipun mengalami penurunan yang paling besar, namun berdasarkan tabel di atas terlihat dengan jelas jika sektor transportasi dan pergudangan yang memiliki angka paling besar diantara sektor - sektor lain. Sehingga bisa dikatakan jika sektor ini paling berpengaruh terhadap PDRB di Kota Padang pada saat periode tersebut. Meningkatnya sektor transportasi dan pergudangan di Padang tentu nya memiliki beberapa alasan. Meningkatnya sektor transportasi dapat disebabkan karena jumlah kendaraan yang juga semakin meningkat untuk dijadikan sebagai sarana pengangkutan. Untuk transportasi darat, Kendaraan pribadi bertambah terutama pada kendaraan roda dua dan roda empat merefleksikan jika terjadi peningkatan.

Berpindahnya transportasi darat pada masyarakat, dari transportasi umum ke transportasi pribadi tentunya dapat memberikan dampak positif maupun negatif terhadap perekonomian. Untuk dampak positif, peningkatan penggunaan transportasi pribadi diprediksi dapat meningkatkan pendapatan terhadap retribusi parkir. Selain itu, permintaan bahan bakar untuk transportasi tersebut bisa juga akan mengalami peningkatan yang lebih sehingga memberikan dampak yang baik. Dan untuk dampak negatif karena meningkatnya penggunaan transportasi pribadi, secara khusus pada transportasi darat, dapat mengakibatkan kemacetan lalu lintas yang dapat menghambat distribusi atau pengiriman barang dan jasa.

Selain kendaraan pribadi, kendaraan besar di Kota Padang juga cukup banyak. Banyaknya kendaraan besar di Kota Padang dikarenakan terdapat cukup banyak perusahaan-perusahaan yang tentunya sangat membutuhkan kendaraan besar tersebut, contohnya perusahaan semen. Selain dibutuhkan beberapa perusahaan, kendaraan besar 
Agika Wasinta Br Sembiring, Silvya Rehgina Gumolung, Rahel Nur Hamidah, Widiana Yeny, Michael Owen

juga dibutuhkan masyarakat untuk mengangkut barang-barang mereka masuk dan keluar Kota Padang. Kota Padang merupakan salah satu Kota di Indonesia yang terkenal dengan pariwisatanya. Banyaknya wisata di Kota Padang berpengaruh juga dengan sektor transportasi di Kota Padang. Misalnya seperti angkutan udara, angkutan rel, dan angkutan pantai atau sungai. Penggunaan angkutan-angkutan tersebut tentunya memberikan pengaruh terhadap meningkat atau menurun nya sektor transportasi yang tentunya juga akan berdampak terhadap PDRB di Kota Padang.

Pembangunan pergudangan di Kota Padang pada tahun 2019 mengalami peningkatan yang signifikan. Hal ini terjadi karena meningkatnya sektor perdagangan yang semakin pesat dan membutuhkan sarana untuk penyimpanan. Dan semakin banyak juga perusahaan - perusahaan yang membutuhkan tempat untuk menyimpan keperluan atau barang - barang tanpa mengganggu kegiatan di perusahaan.

Untuk penurunan pada sektor transportasi dan pergudangan pada tahun 2020 salah satunya terjadi karena munculnya covid-19. Pengamat transportasi yang berasal dari Universitas Andalas (Unand) yaitu Yosafra mengatakan jika akibat yang ditimbulkan dengan adanya pandemi covid-19 terhadap sektor transportasi cukup besar. Dampak tersebut paling terkena pada transportasi umum seperti angkutan kota yang sebelumnya memiliki cukup banyak penumpang namun ketika adanya pandemi covid19 hanya bisa menambang 2 hingga 3 kali dalam seminggu. Hal tersebut menyebabkan biaya operasional tidak tertutupi. Ia juga mengatakan jika dampak dari pandemi covid19 banyak perusahaan transportasi angkutan umum yang tumbang dan bangkrut. Ketua Organisasi Angkutan Daerah (Organda) di Kota Padang yaitu Mastilizal juga mengatakan jika pada saat sebelum pandemi ada sekitar 1.000 angkutan kota di Padang, namun akibat adanya pandemi yang masih terus beroperasi hanya sekitar 250 unit dikarenakan sepinya penumpang.

Untuk penurunan di tahun 2020 pada sektor pergudangan dapat terjadi dikarenakan munculnya covid-19 membuat cukup banyak tekanan. Sehingga masyarakat maupun perusahaan lebih memilih dalam bertindak. Menurunnya sektor pergudangan dapat terjadi dikarenakan melemahnya ekonomi suatu masyarakat maupun perusahaan, sehingga pembangunan pergudangan pun ikut menurun. Bukan hanya untuk membangun, jika dilihat dari melemahnya ekonomi pada pandemi, bisa saja banyak gudang-gudang hancur ataupun digunakan untuk yang lainnya.

\section{Kesimpulan}

Berdasarkan hasil analisis penulis, pengaruh sektor transportasi dan pergudangan terhadap PDRB di Kota Padang pada tahun 2018 - 2020 berpengaruh baik. Alasannya dikarenakan pada tahun 2018 dan 2019 meningkat daripada tahun sebelumnya karena terjadinya peningkatan permintaan di sektor transportasi, sedangkan pada tahun 2020 mengalami penurunan dari tahun sebelumnya karena terjadinya pandemi covid-19. 
Pengaruh Sektor Transportasi dan Pergudangan Terhadap PDRB di Kota Padang

Periode $2018-2020$

Adapun rekomendasi yang penulis berikan adalah, penulis merekomendasikan agar kedepannya masyarakat dan pemerintah dapat tetap bekerja sama untuk dapat bekerja sama memberikan pengaruh yang baik terhadap PDRB di Kota Padang, sehingga dapat meningkatkan PDRB di Kota Padang. 
Agika Wasinta Br Sembiring, Silvya Rehgina Gumolung, Rahel Nur Hamidah, Widiana Yeny, Michael Owen

\section{Bibliography}

Abushaikha, I., Salhieh, L., \& Towers, N. (2018). Improving distribution and business performance through lean warehousing. International Journal of Retail \& Distribution Management.

Apriyani, A., \& Pulungan, N. A. F. (2020). The Effect Of Economic Value Added (Eva) On Price To Book Value The Role Of Institutional Ownership In Retail Sector Companies Listed On The Indonesia Stock Exchange. Dinasti International Journal of Economics, Finance \& Accounting, 1(5), 889-904.

Bintang, A. B. M., \& Woyanti, N. (2018). Pengaruh PDRB, Pendidikan, Kesehatan, Dan Pengangguran Terhadap Tingkat Kemiskinan Di Jawa Tengah (2011-2015). Media Ekonomi Dan Manajemen, 33(1). http://dx.doi.org/10.24856/mem.v33i1.563

Fahlewi, R., Amri, R. R. C., \& Sari, A. M. (2020). Analisis Pengaruh Tingkat Pendidikan, Angkatan Kerja dan Pengeluaran Pemerintah Terhadap PDRB di Provinsi Sumatera Selatan. COSTING: Journal of Economic, Business and Accounting, 4(1), 354-363.

Hanif, M., \& Bustamam, B. (2017). Pengaruh Debt To Equity Ratio, Return On Asset, Firm Size, dan Earning Pe Share terhadap Dividend Payout Ratio (Studi pada Perusahaan Manufaktur yang Terdaftar di Bursa Efek Indonesia Tahun 20112015). Jurnal Ilmiah Mahasiswa Ekonomi Akuntansi, 2(1), 73-81.

Maharani, D. (2017). Analisis Pengaruh Investasi Dan Tenaga Kerja Terhadap Produk Domestik Regional Bruto (PDRB) Di Sumatera Utara. Intiqad: Jurnal Agama Dan Pendidikan Islam, 8(2), 32-46. http://dx.doi.org/10.30596\%2Fintiqad.v8i2.725

Mahroof, K. (2019). A human-centric perspective exploring the readiness towards smart warehousing: The case of a large retail distribution warehouse. International Journal of Information Management, 45, 176-190.

Manueke, M., Tampi, G. B., \& Londa, V. (2018). Persepsi Masyarakat Tentang Jasa Transportasi Berbasis Aplikasi Online Di Kota Manado (Studi Kasus Di Pt. GoJek). Jurnal Administrasi Publik, 4(51).

Mulia, R. A., \& Saputra, N. (2020). Analisis Faktor-Faktor Yang Mempengaruhi Kesejahteraan Masyarakat Kota Padang. Jurnal EL-RIYASAH, 11(1), 67-83. http://dx.doi.org/10.24014/jel.v11i1.10069

Pitoy, H. W. W., Jan, A. B. H., \& Sumarauw, J. S. B. (2020). Analisis Manajemen Pergudangan Pada Gudang Paris Superstore Kotamobagu. Jurnal EMBA: Jurnal Riset Ekonomi, Manajemen, Bisnis Dan Akuntansi, 8(3). http://dx.doi.org/10.24014/jel.v11i1.10069 
Pengaruh Sektor Transportasi dan Pergudangan Terhadap PDRB di Kota Padang

Periode 2018 - 2020

Sinaga, T. S., \& Hidayat, R. (2020). Pengaruh Motivasi dan Kompensasi terhadap kinerja Karyawan pada PT. Kereta Api Indonesia. Jurnal Ilman: Jurnal Ilmu Manajemen, 8(1), 15-22.

Sugiyono. (2016). Metode Penelitian Kuantitatif, Kualitatif dan R\&D (PT Alfabet).

Sugiyono, P. D. (2017). Metode Penelitian Bisnis: Pendekatan Kuantitatif, Kualitatif, Kombinasi, dan R\&D. Penerbit CV. Alfabeta: Bandung.

Suhartono, D. T. (2020). Gross Domestic Regional Product Reconciliation and Compilation Application Development in Sulawesi Selatan. Jurnal Mantik, 4(3), 2005-2012.

Yulia, A., \& Ningsih, E. S. (2020). Penerapan Anggaran Berbasis Kinerja (Performance Based Budgeting) Dalam Pengelolaan Keuangan Daerah Aceh. Jurnal Ilmiah Mahasiswa Ekonomi Akuntansi, 5058. https://doi.org/10.24815/jimeka.v5i1.15433 